\title{
Together, But Almost Alone? \\ On the Ethno-Political Aspects of Interethnic Interactions of West-Ukrainian Lands in 1867-1914
}

\author{
Ivan S. MONOLATII \\ Zakład Teorii i Myśli Politycznej, Instytut Stosunków Międzynarodowych, \\ Uniwersytet Jana Kochanowskiego, Filia Piotrków Trybunalski \\ Department of Theory and Political Thought, Institute of International Relations \\ Jan Kochanowski University in Kielce, Branch Piotrków Trybunalski \\ ul. Słowackiego 116, 97-300 Piotrków Trybunalski, Poland \\ iwan.monolatij@gmail.com
}

The importance and timeliness of the present article are determined by the fundamental impact that ethno-national communities can have on building inter-ethnical relations as and when they interact. In view of ethnical diversities, the significance of interactionism becomes particularly apparent when one takes into consideration the fact that ethno-nations, as independent subjects, play a certain role in political processes and predictably defend the solutions to inter-group conflicts that satisfy solely their own interests. Initiatives that are offered by at least one of them and directed at changing or saving the existing status-quo particularly under conditions of a ranging system of inter-ethnical relations, induce counter-acting processes. ${ }^{1}$ The societal importance of interactionism is indisputable because common stimuli and group reactions directly affect inter-ethnical relations. The latter, while being a core element in the structure of interactionism of ethno-national communities, is among the factors that have a direct influence on political processes in multi-ethnical countries.

The ambivalence of subject-object relations (direct and indirect) diversifies the phenomenon of interactionism, hence it becomes imperative to understand all of its aspects and take into consideration the specific nature of various contacts among groups. Additionally, the importance and timeliness of the subject matter of this study are defined by some other criteria. These include the dynamics of interethnic interactions, which can make relations among ethno-national communities likely to adjust, as well as the interactionism in the ethno-political sphere among groups of equal or non-equal statuses in the times in which the Western Ukrainian region ethnic groups became politicized.

\section{The Multiethnic Structure of the Region}

The multiethnic structure of the Western Ukrainian population, its specific quantity and quality, and conditions of ethno-national communities predetermined socio-cultural and ethno-cultural dimensions, as well as the existence of an ours-stranger dichotomy. The eth-

1 See: Raphael LUTZ, Imperialle Gewalt und mobilizierte Nation. Europa 1914-1945, München 2011; Philipp THER, Die dunkle Seite der Nationalstaaten. Ethnische Sauberungen im modernen Europa, Gottingen 2011; Максим ГОН, Особливості міжетнічної взаємодії в контексті політичних процесів на західноукраїнських землях у міжвоєнний період, Рівне 2006. 
no-national and ethno-social population structure of the region has become an objective background for problem studying. ${ }^{2}$ Herewith, the specific features of inter-ethnic interactions in the context of political processes in times of transition can be explained by a combination on facts about the social, economic and political situation of ethno-national communities. The analysis of the ethno-social structure of the region has led to the conclusion that there was a difference in area and dispersed life styles of Ukrainians, Poles, Jews and other immigrating minorities. In addition, it also shows that the majority of ethno-national communities that resided on the Western Ukrainian territories during the studied period was socially unstructured. On the other hand, the interethnic distance that existed in the Western Ukrainian ethno-political sphere both in terms of social and ethno-psychological discourses, defined the lines of social division between the urban and the rural, cultural labour division, specific life styles of the region's ethnic groups, as well as an intersection of interests of strangers and ours.

The studied region can be treated as a special device that erects social boundaries between ethno-social groups for which an ethnic factor and a political context played a vital part in the period of transitions. Western Ukrainian areas became a special arena for political demands, which were made by ethno-religious communities as a response to a heavy colonizing pressure from other ethnic groups during the medieval and modern times when the autochthonous Ukrainian population was stateless.

In the period of transition, in the Western Ukrainian land ethnic differences used to coincide with those of the social nature. However, in both studied provinces of Austria, i.e. Galicia and Bukovina as a whole and in each individual province in particular, the correlation between different social and ethnic groups differed. ${ }^{3}$ Typical social dividing lines between the urban and the rural modified the counteracting triangle that consisted of a multi-ethnic city (first of all with the Polish and Jewish population), a Christian village (populated with majority Ukrainians) and a Jewish 'shtetl'. The population of Galicia was made up of two large competing groups of Poles and Ukrainians, when in Bukovina those were Romanians and Ukrainians. The Jewish minority had always been the third tangible player. While in Galicia all landowners were Poles without any exception, and peasants were mainly Ukrainians, in Bukovina the first ones were Romanians and Poles, and the second group consisted of Ukrainians and Romanians for the most part. However, for Bukovina this division was not absolute. Both in Galicia and Bukovina, Jews played the part of an intermediary between the first and the second. They had an exclusive role as an innkeeper, a merchant and a landlord. The counteracting triangle of a Ukrainian-Pole-Jew was supplemented with German/ German speaking and Romanian officials (in Galicia and Bukovina respectively), and in an ethno-social composition their parts were utterly different. While taking into consideration the chronotope of the study, the majority of the population were made up of rural inhabitants who were predominantly Ukrainians. For some time, they were said to be a people of 'serfs and popes'. It was only in the late $19^{\text {th }}$ Century when the situation began to change

2 Іван МОНОЛАТІЙ, Особливості міжетнічних взаємин у західноукраїнському реґіоні в Модерну добу, Івано-Франківськ 2007; Iwan MONOŁATIJ, Viribus Unitis? Dylematy (współ)istnenia narodów Galicji Habsburskiej, Lublin 2013.

3 Karlheinz MACK, Galizien um die Jahrhundert Wende. Politische, soziale und kulurelle verbindungen mit Österreich, Wien - München 1990, 12-20. 
due to the emergence of the secular intelligentsia. Minor nobility took a separate niche in the ethno-social body and identified itself mostly with the Ukrainian population. However, as it lived in its airproof nobility environment, it remained, in fact, separated from the wider Ukrainian community. ${ }^{4}$ On the other hand, within the region Ukrainians made up only a small part of the urban population, as only every other tenth Ukrainian in the Western Ukrainian area including the Transcarpathian area was a city dweller, when for Poles and Jews this ratio was far higher. Taking into consideration the conditions and the role of a city in the public life of that period, this fact meant that the Ukrainian community was by large deprived of any control not only over the state power and governance, provincial and local self-governance, but also over industrial production, social infrastructure, modern communications, etc. The Ukrainian ethnic group retained their numerical superiority, but in terms of its influence on societal and social-economic processes, it succumbed to Poles, Romanians, Germans and Jews. The underdeveloped social and professional structure of the ethnical majority was a result of a long-lasting suppression and stateless status. Mass labour immigration, severe social and economic situations, high mortality, a purposeful de-nationalisation and colonisation of the Western Ukrainian lands became heavily unfavourable factors for Galician and Bukovinian Ukrainians. ${ }^{5}$

During the studied period, the share of the Ukrainian population gradually decreased. The Western Ukrainian urban population consisted largely of Poles who were craftsmen, merchants, workers, liberal professions and officials. In Bukovina, they were replaced with Romanian burgers. However, most of the Jews remained among the urban poor in spite of their trade or craft occupations. The societal top tier was taken by rabbi families from Orthodox Jews and 'tzadiks' from Hassidic Jews, but the lower strata of the Jewish population was poor, socially and legally deprived. Richer and better-educated Jews tried to undertake new roles of landowners, entrepreneurs, and liberal professions. ${ }^{6}$ Their majority assimilated into the local German or Polish environment, and seldom into the Ukrainian milieu. Inter-ethnical social distance, as well as the stranger and ours social-cultural dichotomy caused by the community's cultural resources became the factors that triggered the ethnic principle of how members of a Western Ukrainian ethnic group were structured politically. This century-long coexistence of the unique semiotic opposition stranger-ours was a reflection of numerous aspects, like ethno-religious problems, a societal counterpoise, cultural mutual influences, a myth of the neighbourhood. By large all of these were rooted in stereotypes of a stranger perception. Consequently, inter-ethnical relations in the Western Ukrainian areas were far from being univalent and able to 'fit' a single pattern. Interestingly, those relations had a diverse character, i.e. friendly, neutral, unequal, and inimical. Their amplitude swung between the pole of good will, lenience, cooperation, and above all economic and cultural dialogue, and the pole of isolationism, intolerance, suspicion, estrangement and even hostility. Different religions, i.e. Christianity (including the Catholic Church, Armenian and Greek Catholic Church, Orthodox, Protestant) and Judaism,

4 Ярослав ГРИЦАК, Пророк у своїй вітчизні. Франко та його спільнота (1856-1886), Київ 2006, 43.

5 Rudolf WAGNER, Der Parlamentarismus und nationale Ausgleich in der ehemals österreichischen Bukowina, München 1984, 123-127.

6 Teresa ANDLAUER, Die judische Bevolkerung im Modernisierungsprozess Galiziens (1867-1914), Frankfurt am Main 2001, 145. 
different ethnic groups (Ukrainians, Poles, Romanians, Moldavians, Germans, Armenians, Russians, Jews, and others), representatives of utterly different civilizations, i.e. Byzantium, Latin and Near East, co-existed and interacted here. The studied area was a modus of cultures that belonged to leading ethnic nations, i.e. a noble Pole, a boyar Romanian, as well as a traditional Ukrainian and Jewish one. However, Christian and Jewish traditions were most imposing. Herewith, the dividing line between them was most distinct. Nevertheless, despite socio-cultural isolationism and mutual estrangement, these tendencies were not the only ones that defined the picture. ${ }^{7}$

The division of the studied chronotope into the so-called ethnic ghettos clearly exposes an interethnic socio-cultural distance that mutually separates those of strangers residing on the Western Ukrainian lands. Interactions of the ethnic majority with the representatives of other ethnic groups were either changed completely or considerably modified. For example, the way Poles, Romanians, Moldavians or Germans were perceived did not suffer from any barrier, and in general, they were marked with a relatively neutral statement of otherness, while in the case of Jews those barriers were relatively stable. The attitude of non-Jews to Jews can be described by the term "other ours". Therefore, with a view to a self-sufficient value of solitude, the existing interethnic separation was for mutual benefit. Distinct features of the ethno-social development of the region found their reflection in fixed mass stereotypes, when a peasant was associated with a Ukrainian, a landowner with a Pole or a Romanian, and a merchant - with a Jew. Ukrainians gradually assimilated the representatives of other nationalities, and this trend became vivid for contemporaries and took place 'at the bottom', first of all in rural communities, where Ukrainians were undeniably a majority and the Ukrainian folk culture with its rich traditions dominated. ${ }^{8}$ Alternatively, an assimilation process moved up-to-down taking those Ukrainians who belonged to the societal upper crust (gentry, intelligentsia, clergy, and burgesses). The specific character of the ethno-national and ethno-social structure of the Western Ukrainian population in the period of transition led to further aggravation of relations between Ukrainians and other ethno-nations, thus causing additional difficulties in the dialectics of interactions of stranger and ours ethno-nationalisms. Despite a formal equality of all ethnic groups, ethnic minorities dominated in the political, economic and cultural life of Galicia and Bukovina, as part of Austria-Hungary. Representatives of national minorities noticeably dominated in economically advanced strata, among city and town dwellers, they had a greater influence than that of Ukrainians on the political power and local self-government. ${ }^{9}$

Therefore, the stranger-ours dichotomy existed, as it was an inter-related complex of religious symbols, a living language of daily communications, as well as reflective conceptions of an individual or a certain group of individuals. Religious, ethnical, social or other features differentiated them from the general environment. A territory, as a background for an interaction of ethno-national communities, and a firing ground for a desperate battle for scarce

7 Іван МОНОЛАТІЙ, Разом, але майже окремо. Взаємодія етнополітичних акторів на західноукраїнських землях у 1867-1914 рр., Івано-Франківськ 2010, 110-114.

8 Іван МОНОЛАТІЙ, Інші свої. Політична участь етнічних акторів пізньогабсбурзьких Галичини і Буковини, Івано-Франківськ 2012, 78-84.

9 Hans-Peter HYE, Das politische System in der Habsburgermonarchie. Konstituonalismus, Parlamentarismus und politische Partizipation, Praha 1998, 145. 
resources (first of all, for the land) became a determining factor of the stranger-ours opposition. Apparently, this led to the next step of group dissatisfaction, which worked as a correlating factor of strangers-ours interactions. In 1867-1914, in the Western Ukrainian area, social and ethno-cultural dimensions of the stranger-ours dichotomy were also defined by another important circumstance. In the modern times with their numerous innovations in various spheres of the public life, a new identifier, an ethnic identifier came into being and slowly fought for its right to exist next to the religious one.

In the studied chronotope, political parties, structured in accordance with the ethnic principle were an immediate subject of the political process. As some political players articulated we-interests outside their surroundings, this encouraged the socialization of ethnic group members who through the mediation of parties directed their activities at implementing the interests of ethnic groups. The ideology of the parties that were established on the basis of the ethnic identity and operated in the Western Ukrainian area reflected the interest of party members. The key defining features of the political culture often were the protection of their own interests, readiness to satisfy those interests by means of 'strangers', as well as numerous objective reasons for interethnic antagonisms. They resulted in the ethno-political situation where political actors of various ethnic communities personalized mostly competing or conflicting institutionalizing forces. Despite the discrepancies in the ideology and the availability of their own full-scaled spectrum of forces, ethnic parties were unanimous and adamant in demanding to restore their own states. The versatility of their demands was substantially modified depending upon the availability of a social base for political players and a variety of social values preached by individual bearers of ethnic features. In particular, this could be domination of a progressive or on the contrary conservative world-view, a support of different scenarios of societal progress and means of its achievement. They became apparent, as Austria-Hungary was modifying its political system, and specifically when it established an efficient system for managing ethno-national processes. ${ }^{10}$

First and foremost, it was the multinational population of Austria-Hungary with its ethno-national structure made up of the so-called state peoples (Germans and Hungarians) and ethnic minorities that caused the implementation of the priorities of the ethno-national state policy. Hence, 1860s Habsburg's state ethno-policy included equal constitutional rights and freedoms, equality for all citizens disregarding their ethnic origin, as well as guarantees that citizens of the dualistic imperia who belonged to different ethnic and religious communities had a full and equal right to participate in all spheres of the public life of the country. In a relatively short time span, the Habsburg empire as a dualistic state managed to introduce effective methods with which to influence and harmonize the interests of different ethnic communities, as well as to develop the strategies that incorporated those interests in the ethnic state policy. ${ }^{11}$ However, in its essence the ethnic policy cannot be defined as a harmony of groups in the ethnic diversity. In the ethno-national sphere, the empire experienced numerous problems that naturally occurred in the process of ethnic revivals started by various ethnic communities. Other difficulties were triggered by the

10 See: Waldemar ŁAZUGA, Kalkulować... Polacy na szczytach c.k. monarchii, Poznań 2013.

11 Andrzej DZIADZIO, Monarchia konstytucyjna w Austrii 1867-1914. Władza - obywatel - prawo, Kraków 2001, 83. 
inertia that existed in the ethno-national sphere as a relatively autonomous sub-system of the society. Current methods and procedures for ethnic individuals to exercise their rights required further reformation and improvement. This implied principles of building special advisory bodies that were made up of national minorities and worked at local self-government. It also included the ways, in which individuals from a national minority could exercise their rights personally and through the mediation of national societies and ethnic parties (in particular, this as some sort of final but late accord took place after the collapse of Austria-Hungary in the times of Western Ukrainian People's Republic [Західно-Українська Народна Республіка] in 1918-1919).

Facts proved that the state applied confrontation methods against strangers. This implied first of all the installation and conservation of vertical inter-ethnical relations, satisfaction of interests of the leading ethnos by means of strangers. The latter, Jews in particular, while being 'on their way to equality' had not been yet recognized as a separate nation, which testified to the segregation model of inter-ethnic relations applied to them. In the studied chronotope (in Galicia, in particular) state bodies pursued attacking policies towards group interests, mostly those of Ukrainians and Jews. Vertical inter-ethnical relations ended up in positioning the state as an unconditional defender of the interests of the leading (Polish) ethno-nation in the region. Under those conditions, the state faced the dilemma of whether to create opportunities for ethnic minorities to nurture their cultural resources, to obtrude socio-cultural values of the state nation upon those minorities or to combine such values in harmony with those of strangers through dedicated policies and methods. ${ }^{12}$ Such a dilemma reflected the focus of the ethnic leaders, on one hand, on implementing an ethno-political model of the state (as declared by the ruling dynasty and the government), and on the other hand, propagating an ethnic or political concept of the nation. This resulted in mobilizing members of ethnic groups and evolving strategies for inter-group interactionism.

During the transition period, the evolution of group interactionism strategies in the Western Ukrainian area manifested itself in its level of influence (open and publicly declared, or hidden, latent forms) and worldview parameters (an influence of the national psychology, socio-historical experience, etc.). Such strategies being aggregated by parties in a form of objectives, the implementation of which could facilitate the position of 'ours', became evident in party programmes, flyers and addresses, propagating publications, and public literature. The latter included the works written by those who laid claims for an ethnic leader status or at least represented a core of most active members of parties or public institutions.

\section{The Ethno-Political Mobilization \& the Ethno-Political Behaviour}

An ideological factor played the most significant part in the ethno-political mobilization of the West-Ukrainian community. In fact, all ethnic minority organizations (national societies, political parties) created a certain ideology that reinforced their group solidarity. The ideological factor had a great power that encouraged unification and further actions. A political

12 Seе: Віра БУРдяК, Національні рухи в Центрально-Східній Європі: теоретико-методологічні підходи до проблеми, in: Форум. Суспільно-політичний журнал, 5, 2007, 2, 73. 
interest was one of the criteria for ethno-political mobilization. Such factors as 'insecurity' and the so-called principles of justice played a particular role in the political mobilization of minorities, as well as other groups. Most likely, these factors were the most effective under the circumstances of ethno-political mobilization. Therefore, during the studied chronotope, ethnic parties used them as political slogans. Such criteria as the authority of a party or a national society representing minority interests, and influential ethnic leaders also had a vital importance in the process of ethno-political mobilization of the community. These could be explained by the level of national self-consciousness of a group, its ethnic culture, understanding of the problems of ethnic development and ways out, the level of ethnic identity, and ethnic leadership as a powerful consolidating factor. ${ }^{13}$

An ethno-political mobilization factor proved that ideological and organizational impacts of political parties that operated in the Western Ukrainian region in the transition period worked as a tool that converted the power of ethno-national communities of equal or different statuses into a mobilizing impact on the party masses, i.e. a member of an ethnic party, a party follower and as a result a potential elector. Hence, one could witness a process of ethno-political mobilization when a politician and/or an activist organized and brought together potential voters to support a candidate and/or a political party programme. The evolution of group interactionism strategies of the studied chronotope had three stages of ethno-mobilizing processes of national minorities: latent, organizational and political. ${ }^{14} \mathrm{At}$ the first stage, minorities declared their existence only nominally, therefore this stage was characterised by quick assimilation and dispersion of national minorities. At the second stage, ethno-national communities became active participants of internal political processes. Thus, later they reached the third, political stage. It was characterised by creating political movements and parties that took part in elections of different levels (up to regional councils - Seim) and in the political life of the state (Reichsrat).

The similarity of objectives, which were articulated by Ukrainian and Polish political players (an ethno-political renaissance, in particular) became apparent at the very beginning of the transition period. Attacking policies against strangers were pursued by Poles first of all in Galicia and then Romanians in Bukovina. In interactionism strategies, Jewish and German groups applied the tactics aimed at protecting their ethno-group interests and co-existing with others, often dissimilar in the religious aspect communities (Ukrainians, Jews). Overall, ethno-political mobilization of ethnic minorities of the studied period ensured their transition into an ethno-nation. Noteworthy, as a result, is that ethnic minorities often failed to act as a monolithic formation. When united in a much stronger organisation, representatives of different political parties (Bukovina Germans, for example) often fought for leadership. Lastly, the ethno-political mobilization turned ethnic groups residing in the studied territories into potential political players. In the Western Ukrainian area, in the period of transition, the ethno-political mobilization factor served as an alternative to assimilation with dominating nations and occasionally manifested itself in strengthened communications, conducted joint events and declaration of their active life stand in relation to this or

13 Marianna HAUSLEITNER, Die Rumanisierung der Bukowina. Die Durchsetzung des nationalstaatlichen Anspruchs Grossrumaniens 1918-1944, München 2001, 345-348.

14 Iwan MONOŁATYJ, Etnopolityczne aspekty polityki narodowościowej Austro-Węgier w Galicji 1867-1914, in: Nowa Ukraina. Zeszyty historyczno-politologiczne, Kraków 2006, 9-12. 
the other political decision made by the centre. ${ }^{15}$ Ethnic mobilization and active participation in social and political processes proved that in the transition period ethnic subjects of the studied chronotope became noticeable players at the political chessboard.

Subjects and ethno-political trends were defined by the ethno-national policies of the Austrian state that was institutionalized in the Western Ukrainian area in the transition period, as well as by ethno-group interests and defence strategies articulated by parties. The priorities of the Habsburg's ethno-national policies in the studied chronotope were the result of state institutionalization, as well as the result of the ethnic movements that accomplished their core objectives. Austria-Hungary's strategy in the ethno-political domain was based mainly on two factors: the ethno-demographic one and the chosen ethno-political model of its development, which implied harmonized relations between the state and ethnic minorities. Initiatives of the ruling dynasty and governments of the Danube monarchy in the realm of ethno-political policy, which was rooted in ethno-pluralism, could be narrowed down to the following triad: to ensure state sovereignty, to preserve territorial integrity and to achieve a sustainable political system. However, due to the discrepancies in the way the state perceived strangers and ours, legitimacy of the power became a means with which to reach such objectives. As an additional instrument and due to the strengthening of the statehood in general, official Vienna pursued a course of securing multiculturalism as a guarantee of the tolerant co-existence of ethno-national communities. ${ }^{16}$ Overall, central government activities in the sphere of ethno-national relations testified to the fact that it was ready to provide sound conditions to preserve the cultural resources of ethnic minorities and to abort relations of inter-ethnical subordination.

Efforts of the state aimed at building an above-nation multiethnic political nation resulted in the establishing/functioning of the competing groups that were represented by political players who, depending upon the status of their ethnic subject, played an ambivalent role. Those who were nurtured by the environment of the leading ethnos defended state interests, and the others, which united members of ethnic minority groups, protected against the dictatorship of the first ones. Attempts to politicise the so-called offended ethnicities became a prerequisite for the successful protection of their interests. The reaction of ethnic minorities to the uncovered prejudice of regional authorities and a vertical system of inter-ethnic relation created by the state were mostly defensive. Herewith, they became the subjects that exhibited an attacking behaviour concerning other ethnic communities, but never against the nation-state. On one hand, this resulted in an assault of the state and its dominating nation on the rights and group interests of ethnic minorities, and on the other hand, a clash of interests of communities of equal and different statuses.

In the ethno-political behaviour of ethno-national communities of the studied chronotope, we differentiate the following distinctive features: protection of languages, demands to

15 See: Sepp MÜLLER, Von der Ansiedlung bis zur Umsiedlung. Das Deutschtum Galiziens, insbesondere Lembergs. 1772-1940, Marburg am Lahn 1961; Małgorzata ŚLIŻ, Galicyjscy Żydzi na drodze do równouprawnienia 1848-1914. Aspekt prawny procesu emancypacji Żydów w Galicji, Kraków 2006.

16 Gerald STOURZCH, Czy Żydzi w dawnej Austrii uznawani byli za narodowość?, in: Ze sobą, obok siebie, przeciwko sobie: Polacy, Żydzi, Austriacy, Niemcy w XIX i na początku XX wieku, Kraków 1995, 70-107; Iwan MONOLATIJ, Deutscher Diskurs der westukrainischen ethnopolitischen Sphäre, in: Форум. Суспільно-політичний журнал, 7, 2008, 2, 57-62. 
introduce autonomy in its territorial and non-territorial variants, reforming of the election law, a fight for favourable conditions to preserve cultural resources of the ethnicity, and protection of other group interests. Numerous party institutions or other political figures articulated ethno-nationalisms and represented ethno-group interests of subjects of the political processes of the studied period. On one hand, objectives for ethnic consolidation, which were aggregated by political players and ethnic leaders, defined the patterns of ethno-political behaviour of ethnic groups that was aimed at obtaining full civic and ethnic rights. On the other hand, the attacking strategy of the central power aimed at integrating subordinated groups into one imperial organism, which worked as a catalyst for shaping the political behaviour of ethnic minorities.

The presence or absence of their claims on limited resources, power in particular, became a determinant factor that influenced the character of ethno-political behaviour of the groups during the evolution of ethnic identifiers. The political behaviour of individual bearers of an ethnic culture representing ethno-nations oscillated widely from an active participation in ethnic movements or, on the contrary, counter-position to the new power or inertial contemplation as to how a new ethno-political organism got institutionalized on the Western Ukrainian lands. The period of transition offered dispersed ethnic minorities that demonstrated integrating ethno-political behaviour a time space for adaptation to new societal and political realia. For this reason, the pattern of ethno-behaviour on the basis of tendencies that dominated at a group level was characteristic mostly of reactions/answers by ethno-national communities to external challenges aimed at protecting group interests and values. Different objectives that ethno-area and dispersed communities tried to achieve in the times of politicization of ethnicities resulted in different dominants in ethno-behaviour of the subjects of interethnic interactions. The intersection of demands of ethnic minorities included the demand for autonomy within its territorial and national-cultural variants, civic equality, etc. ${ }^{17}$

The ethno-political behaviour of subordinated groups testified to the presence of two major platforms, where they could reach a compromise. Those implied cooperation in developing statehood and an opposition to the state. The latter turned out to be unacceptable for all ethno-national communities on the Western Ukrainian lands, particularly for Jews and Germans. In order to reach parity in rights with the nation-state, all ethnic minorities without any exception strove to create favourable conditions to preserve their own cultural resources. This defined the key criterion in the way they saw a compromise for ethno-national communities of different statuses, which implied an integration into the state as subjects of the political nation with equal rights. At the same time, the absence of common large-scaled campaigns run by ethnic minorities and aimed at their integration into the ethno-political organism of the Habsburg's monarchy as equal subjects, and the lack of mutual support proved that their cooperation was occasional and did not represent a dominant trend in dual or multiple interactions.

17 Jolanta ŻUNDUL, Państwo w Państwie? Autonomia narodowo-kulturalna w Europie Środkowowschodniej w XX. wieku, Warszawa 2000, 11-20. 


\section{Interactions Of Ethno-National Communities: Conflicts and Dialogues}

Interactionism of ethno-national communities of different statuses was modified by the discrepancies in the interests of Ukrainians and immigrating communities, as well as their response to the attempts of one of the subjects of interactions to achieve the objectives that contradicted the interests of subordinated groups, as well as the readiness/non-readiness of the latter or their representatives to protect they-interests. Political positioning of disperse communities was of particular importance, as it defined the character of reaction patterns of the autochthonous ethnic majority of the Western Ukrainian region.

Both objective and subjective reasons obstructed the cooperation of groups of different statuses. Former reasons included the natural prevalence of we-interests in ethno-group consciousness, and as a result, the inability of the majority of ours ethnic individuals to make a step for the benefit of strangers, and permanent dead-end situations of disperse ethnic minorities, in which their loyalty was requested by both Poles and Ukrainians at one and the same time. Subjective reasons included the absence of a platform built by ethnic minority political players in order to resolve their problems in the most complex manner, the political will of immigrating communities to support fair demands of the ethnic majority of the region and the political culture that would take into consideration the consequences of bilateral partnership for the third party. ${ }^{18}$

The language became another vital element that galvanized the disputes on values between ethno-national communities of different statuses. Attempts of subordinated groups to protect this important cultural resource catalysed their ethno-political mobilization. This tendency found its vivid reflection in the fight of ethnic minorities for a native language school and those societal values that corresponded to their we-interests. It was supplemented with the demands to increase the number of educational institutions to be financed from the public budget, widen the opportunities for ethnic minorities to gain vocational and professional training, as well as higher education.

The competition of ethno-nationalisms that was prompted by the efforts of ethnic minorities to protect their cultural resources, i.e. to preserve the space for a socio-cultural distance, on one hand, and the attempts of the authorities to ruin it by imposing we-values on strangers on the other hand, defined the latent essence of value disputes and conflicts between different ethnic subjects of interactions. ${ }^{19}$

An integration of subordinated groups into the ethno-political organism of the empire took place in three directions, i.e. language and communications, political and legal, and social-economic. The ethnic factor significantly influenced each of the three. In the first place, the state built a single information space and the German-speaking environment disregarded cultural diversity and proclaimed tolerance. This task was of paramount importance on the road to shaping a state identity and territorial patriotism. It was complement-

18 Dariusz MACIAK, Próba porozumienia polsko-ukraińskiego w Galicji w latach 1888-1895, Warszawa 2006, 189-200; Ortfried KOTZIAN, Der Bukowina-Ausgleich 1910: Beispiel einer Lösung ethnische-religiöser Konflikte, in: Bukowina. Wspólnota kultur i języków, Kazimierz FELESZKO - Jerzy MOLAS (eds.), Warszawa 1992, 11-18.

19 Jan KOFMAN, Nacionalizm gospodarczy - szansa czy bariera rozwoju. Przypadek Europy Środkowo-Wschodniej w okresie międzywojennym, Warszawa 1992, 297. 
ed with the demand to nurture a loyal to the ruling dynasty population and to decrease the number of ethnic individuals who were dissatisfied with the work of the central and local government, i.e. political and legal integration. In the studied period, the state recognized and applied certain political instruments to legitimize its supremacy. In this matter, it tried to (re-)construct relevant samples that could help to find one's way in the political space of the subjects of the Western Ukrainian ethno-political sphere. Those orientation samples structured the interpretation of inter-ethnic interactions, so that the subjects of the ethno-political sphere could understand their experience connected with the liberal theory of the state and integrate it into their life space. ${ }^{20}$

Interethnic interactionism of ethno-national communities of the Western Ukrainian lands in the period of transition was known for a chain of political disputes and conflicts. As political players and ethnic leaders responded to real or perceived injustice, conflicts and disagreements focused their attention on the rivalry of our and strangers' ideologies. Ethno-political conflicts and disagreements were based on a contraposition of aspirations of different subjects of interethnic interactions, which in dialectics manifested itself as a denial of they-strivings. Initiatives of ethnic groups, which were aimed at changing or saving societal realia, testified to their refusal to interact in line with the 'rules of the game' or vice versa their protection, as well as their intention to impede achieving such results that could be recognized by a competing party. ${ }^{21}$

First and foremost, ethno-social disagreements and conflicts were caused by the ethnic background. While disagreements over sparse resources (land in the first place) became a source of the ethno-social conflict in its latent form, as well as in the form of explicit regional ethno-social conflicts (agricultural strikes in particular), early 1920s competition in the economic area acquired a new specific shape. As a result, the economic rivalry transformed into a pivoting framework for interethnic interactions.

An active struggle, that had different forms and methods between ours and strangers, for land and domination in trade and small-scale production in rural and urban areas was aimed at reaching at least two objectives. The first objective was to force strangers (Jews in villages, Jews and partly Poles in cities and towns), i.e. those who were involved in intermediary activities and represented a merchant stratum, out of economic processes. ${ }^{22}$ The second one was to make the most of psychological pressure, social obstruction, or radical methods of fighting, such as economic boycotts, physical abuse, etc. In a tense societal atmosphere of the ethnic and social exploitation, a part of the ethnic majority of the region, radically minded in particular, resorted to brutal force while trying to compensate for its lack of professional skills, business intuition, as well as other factors that could help to succeed in its fight for the labour market. This situation was aggravated by the unfair economic and administrative policies of the central and regional governments in relation to the

20 See: WAGNER, 123-127.

21 Ryszard TOMCZYK, Radykałowie i socjaldemokraci. Miejsce i rola lewicy w ukraińskim obozie narodowym w Galicji 1890-1914, Szczecin 2007, 203-211.

22 Kai STRUVE, Gentry, Jews and Peasants. Jews as Others in the Formation of the Modern Polish Nation in Rural Galicia during the Second Half of the Nineteenth Century, in: Creating the Other. Ethnic Conflict and Nationalism in Habsburg Central Europe, Nancy M. WINGFIELD (ed.), New York - Oxford 2003, 103-126. 
Ukrainian village, especially while implementing the idea of 'colonizing parcelling'. In the times when on one hand, the region faced the Ukrainian-Jewish-Polish ethno-social rivalry, and interethnic interactions, on the other hand, an uncompromising struggle remained a dominating tendency in the economic area. ${ }^{23}$

Main socio-cultural disagreements in interethnic interactions, sometimes growing in conflicts, were caused by both objective and subjective factors. The former included the fight for the national church under the conditions when ethnic and confessional values were tightly interwoven. The subjective factors included efforts of the government and Polish political players to use religion as an additional means for assimilating strangers, as well as a means for realizing a Catholic version of ethno-nationalism. The driving reason for worsening multi-subject disagreements between groups of different statuses was the attempt of the state and the dominating ethno-nations to level sustainable cultural sub-systems and to assimilate strangers. Besides, the response of the discriminated ethnic majority of the region to acculturation of others triggered the disagreements between the subjects of different statuses. As inter-group disagreements took place in various spheres of public life, we describe two groups of socio-cultural conflicts by their major impacts. The first group included the disagreements and conflicts caused by a religious factor. This implied clashes between different churches, disagreements between churches and the state, and the discrepancies within the church itself. The conflicts caused by the ethnic factor belonged to the second group. They included disagreements between subjects of interethnic interactions over values graded according to social interests. ${ }^{24}$

Peculiarities of the interethnic disagreements and conflict in the Western Ukrainian region in late $19^{\text {th }}-$ early $20^{\text {th }}$ Centuries in their rivalry for sparse resources proved that, in the studied chronotope, ethnicity became a relatively independent conflict-generating factor, and growing ethno-national self-consciousness became one of the key reasons for conflicts in the political, economic and cultural areas. For most studied cases, the main reason for conflict-generating tension was the fact that an ethno-nation tried to set its own values over those of the others.

The co-existence of ethno-nations in the studied chronotope caused a natural 'faceless social order', i.e. a 'neutral' module of their co-being. It appeared as a result of the self-isolation of ethnicities, as well as a consequence of stable and active contacts with strangers. At the same time, contacts that appeared between ours and strangers, or intensification of such contacts instigated the aberration of neutral relations into new qualities. The 'low' level of inter-group interactionism was focused on modelling neutral relations between ethno-national communities of both equal and different statuses. As the absence of evaluation of the given situations did not add anything positive, then such an unemotional condition ascertained a 'passive' positive state, which parties did not managed to reach as a result of their initiatives. Taking into consideration traditional out-group reproaches, saturation of strangers' images added negative colours, rather than predicting a probability of their

23 Czesław PARTACZ, Od Badeniego do Potockiego. Stosunki polsko-ukraińskie w Galicji w latach 1888-1908, Toruń 1996, 189-200.

24 Johannes MARTETSCHLÄGER, Die Rechtsstellung der Kirchen und Religionsgesellschaften in Österreich nach Art. 15 Staatsgrundgesetz 1867, St. Ottilien 1993, 119. 
positive variations. ${ }^{25}$

In most cases, ethnic tolerance remained a constructive element of interethnic interactions in the Western Ukrainian region. Despite the differences that existed in group attitudes to values and norms, ethno-political behaviour and ethno-cultural tradition were characteristic of a relatively common concept of ethnic tolerance, forbearance and compliance. Therefore, tolerance and intolerance had a defining role in practicing violence and non-violence, in the dynamics of integrating and disintegrating processes. As already mentioned, in certain cases the multi-ethnic society of the studied region faced radical tendencies rooted not only in bigotry, but also in the rejection of 'otherness'. This resulted in destructive interethnic relations and consequently in conflicts. Understandably, in the political field, possibilities reached by an ethnicity due to its status gave it a chance for an institutionalised form of ethnic policy of the authorities or nation-state, which were realized by political players, and provided guarantees that ethnic interests would be considered in decision-making. Another sign of ethno-policy in the studied region was the growing opposition of the members of dominating groups to unfair, in their eyes, provision to ethnic minorities of political and civic freedoms. Therefore, the nature of interethnic compromises was linked with the problem of ours-strangers interactions, and consequently interethnic understanding/reconciliation. This meant a special juxtaposition in ethnic group dialogues and a specific 'receipt' of an attitude to neighbours and guests. Hence, the problems of interethnic relations faced by others in the Western Ukrainian region put a new item on the agenda, i.e. a need to search for non-violent solutions and ways of interactions between ethno-national communities. The official concept of the nation-state implied an idea of integration of different groups that would allow, on one hand, subjects of the ethno-political sphere to preserve their specific features, and on the other hand, to ensure their interaction and mutual enrichment by means of equal dialogues. Therefore, both in theory, and in ethno-political practice, which was based on the principles of interethnic group tolerance, the authorities and the nation-state regulated conflicts in the multi-ethnic society by means of turning interethnic disagreements into compromises by ethnic minorities.

In the times when ethnicities were politicised and intensively interacted with other ethnic groups and vigorously competed for sparse resources, ethnic groups and their leaders demanded and stood for preserving their own ethno-cultural traditions. Under such circumstances, there was a need for optimizing intercultural interactions and adjusting them to the terms and rules of the multi-ethnic society. Hence, involvement of the others occurred in the framework of separation (ethno-centric ways of interaction) or integration (ethno-relativistic means), then the culture of interethnic interaction in the Western Ukrainian region implied cooperation of strangers and ours, and regulation of their disagreements at the individual and group levels.

Dialectics of interethnic relations and activities of political players represented mainly a culture of an interethnic competition. ${ }^{26}$ As subjects of interethnic interactions faced the challenge of how to protect their group interests, the competition which was a dominat-

25 Alexander V. PRUSIN, Nationalizing a Borderland. War, Ethnicity, and Anti-Jewish Violence in East Galicia 1914-1920, Tuscaloosa 2005, 181.

26 See: Iwan MONOLATIJ, Politische Partizipation von ethnischen Akteuren im Vielvölkerstaat: Erfahrungen von Galizien und der Bukowina in der Donaumonarchie, in: West Bohemian Historical Review, 3, $2013,1,94-114$. 
ing factor in group interactionism defined a relevant culture of interactions. In particular, interethnic socio-cultural distances and interaction experiences in various spheres of public life facilitated the domination of negative attitudes in the ways ethnic groups perceived and evaluated each other. As tolerance for others was often manifested at an individual level, the mass culture of their interactions was marked by derivatives of non-conformism. Various behavioural patterns of non-conformism differed depending upon an ethno-political situation, but were based on the common denominator of isolating ethno-political behaviour. In view of the dominating tendency in the latter, the type of the culture of interethnic interactions is classified as dialogue- and non-violent-defensive, factors that defined the culture of interactionism of otherness as such that differ in the origin of their statuses and roles.

In the studied chronotope, the problem of group interaction is particularly apparent when looking through the prism of their direct interactionism or separate political players. The initiatives of each of them were such that they had at least a partial impact on changing and/ or setting the moods of our group members towards those of the other ones. In this case, not only their actions towards others were important, but also their readiness, on one hand, to interact on the principles of tolerance, and on the other hand - put forward acceptable for others proposals to regulate contradictions. Contacts between ethnic individuals at the personal level are perceived as an everyday level of the culture of interethnic interaction. These relations, as well as communications between ethnic individuals from two or more communities are a natural consequence of poly-ethnicity in the Western Ukrainian region. This created an objective background for building a space for ethnic contacts where mutual tolerance and good neighbour attitudes dominated and partly dispelled the atmosphere of mutual repulsion.

\section{Abstract}

The article examines the institutional processes in the ethnopolitics of Austro-Hungary concerned with the rights and needs of ethnic actors and the processes of internal and external institutionalization of Ukrainian, Polish, Jewish, Romanian and German political actors in Galicia and Bukovina. The legal basis for the formalization of political participation of citizens and the policy priorities of the state are characterized in terms of ethnic awakening. We trace a genesis of the ethnic catalyst of the political mobilization and determine the relationship between the occupational structure and the lines of social division expressed in the ethnic terms. The platforms and strategies of the political parties founded along ethnic lines are analyzed. We also examine the mobilization factors of electoral and protest participations, the catalysts of competition among ethno-national communities with different statuses, the variability of protection of group interests, and the compromises and consensuses of the formalized and unformalized ethnic actors. 


\section{Keywords}

Austro-Hungary, West-Ukrainian region, politization of ethnicity, political participation, political mobilization, protection of group interests, ethnic conflict, interethnic compromis, interethnic interaction

\section{References}

ANDLAUER, Teresa: Die judische Bevolkerung im Modernisierungsprozess Galiziens (1867-1914), Frankfurt am Main 2001.

БУРДЯК, Віра: Національні рухи в Центрально-Східній Європі: теоретико-методологічні підходи до проблеми, in: Форум. Суспільно-політичний журнал, 5, 2007, 2, 70-77.

DZIADZIO, Andrzej: Monarchia konstytucyjna w Austrii 1867-1914. Władza - obywatel prawo, Kraków 2001.

ГОН, Максим: Особливості міжетнічної взаємодії в контексті політичних процесів на західноукраїнських землях у міжвоєнний період, Рівне 2006.

ГРИЦАК, Ярослав: Пророк у своїй вітчизні. Франко та його спільнота (1856-1886), Київ 2006.

HAUSLEITNER, Marianna: Die Rumanisierung der Bukowina. Die Durchsetzung des nationalstaatlichen Anspruchs Grossrumaniens 1918-1944, München 2001.

HYE, Hans-Peter: Das politische System in der Habsburgermonarchie. Konstituonalismus, Parlamentarismus und politische Partizipation, Praha 1998.

KOFMAN, Jan: Nacionalizm gospodarczy - szansa czy bariera rozwoju. Przypadek Europy Środkowo-Wschodniej w okresie międzywojennym, Warszawa 1992.

KOTZIAN, Ortfried: Der Bukowina-Ausgleich 1910: Beispiel einer Lösung ethnische -religiöser Konflikte, in: Bukowina. Wspólnota kultur i języków, FELESZKO, Kazimierz MOLAS, Jerzy (eds.), Warszawa 1992, 11-18.

ŁAZUGA, Waldemar: Kalkulować... Polacy na szczytach c.k. monarchii, Poznań 2013.

LUTZ, Raphael: Imperialle Gewalt und mobilizierte Nation. Europa 1914-1945, München 2011.

MACIAK, Dariusz: Próba porozumienia polsko-ukraińskiego w Galicji w latach 1888-1895, Warszawa 2006.

MACK, Karlheinz: Galizien um die Jahrhundert Wende. Politische, soziale und kulurelle verbindungen mit Österreich, Wien - München 1990.

MARTETSCHLÄGER, Johannes: Die Rechtsstellung der Kirchen und Religionsgesellschaften in Österreich nach Art. 15 Staatsgrundgesetz 1867, St. Ottilien 1993.

MONOLATIJ, Iwan: Deutscher Diskurs der westukrainischen ethnopolitischen Sphäre, in: Форум. Суспільно-політичний журнал, 7, 2008, 2, 57-62.

MONOŁATYJ, Iwan: Etnopolityczne aspekty polityki narodowościowej Austro-Węgier w Galicji 1867-1914, in: Nowa Ukraina. Zeszyty historyczno-politologiczne, Kraków 2006, 9-19.

МОНОЛАТІЙ, Іван: Інші свої. Політична участь етнічних акторів пізньогабсбурзьких Галичини і Буковини, Івано-Франківськ 2012.

МОНОЛАТІЙ, Іван: Особливості міжетнічних взаємин у західноукраїнському реґіоні в 
Модерну добу, Івано-Франківськ 2007.

MONOLATIJ, Iwan: Politische Partizipation von ethnischen Akteuren im Vielvölkerstaat: Erfahrungen von Galizien und der Bukowina in der Donaumonarchie, in: West Bohemian Historical Review, 3, 2013, 1, 94-114.

МОНОЛАТІЙ, Іван: Разом, але майже окремо. Взаємодія етнополітичних акторів на західноукраїнських землях у 1867-1914 рр., Івано-Франківськ 2010.

MONOŁATIJ, Iwan: Viribus Unitis? Dylematy (współ)istnenia narodów Galicji Habsburskiej, Lublin 2013.

MÜLLER, Sepp: Von der Ansiedlung bis zur Umsiedlung. Das Deutschtum Galiziens, insbesondere Lembergs. 1772-1940, Marburg am Lahn 1961.

PARTACZ, Czesław: Od Badeniego do Potockiego. Stosunki polsko-ukraińskie w Galicji w latach 1888-1908, Toruń 1996.

PRUSIN, Alexander V.: Nationalizing a Borderland. War, Ethnicity, and Anti-Jewish Violence in East Galicia 1914-1920, Tuscaloosa 2005.

STOURZCH, Gerald: Czy Żydzi w dawnej Austrii uznawani byli za narodowość?, in: Ze sobą, obok siebie, przeciwko sobie: Polacy, Żydzi, Austriacy, Niemcy w XIX i na początku XX wieku, Kraków 1995, 70-107.

STRUVE, Kai: Gentry, Jews and Peasants. Jews as Others in the Formation of the Modern Polish Nation in Rural Galicia during the Second Half of the Nineteenth Century, in: Creating the Other. Ethnic Conflict and Nationalism in Habsburg Central Europe, WINGFIELD, Nancy M. (ed.), New York - Oxford 2003, 103-126.

ŚLIŻ, Małgorzata: Galicyjscy Żydzi na drodze do równouprawnienia 1848- 1914. Aspekt prawny procesu emancypacji Żydów w Galicji, Kraków 2006.

THER, Philipp: Die dunkle Seite der Nationalstaaten. Ethnische Sauberungen im modernen Europa, Gottingen 2011.

TOMCZYK, Ryszard: Radykałowie i socjaldemokraci. Miejsce i rola lewicy w ukraińskim obozie narodowym w Galicji 1890-1914, Szczecin 2007.

WAGNER, Rudolf: Der Parlamentarismus und nationale Ausgleich in der ehemals österreichischen Bukowina, München 1984.

ŻUNDUL, Jolanta: Państwo w Państwie? Autonomia narodowo-kulturalna w Europie Środkowowschodniej w XX. wieku, Warszawa 2000. 